medRxiv preprint doi: https://doi.org/10.1101/2020.06.19.20135558; this version posted June 20, 2020. The copyright holder for this preprint

(which was not certified by peer review) is the author/funder, who has granted medRxiv a license to display the preprint in perpetuity.

It is made available under a CC-BY-NC-ND 4.0 International license .

\title{
1 Five years functional connectivity reorganization without clinical or cognitive decline in MS
}

2

3 Einar August Høgestøl ${ }^{*}, a, b$, Samuele Ghezzo ${ }^{*}, c, d$, , Gro Owren Nygaard ${ }^{a}$, Thomas Espeseth ${ }^{e, f}$, Piotr Sowa ${ }^{g}$,

4 Mona K. Beyer ${ }^{b, g}$, Hanne Flinstad Harbo ${ }^{a, b}$, Lars T. Westlye ${ }^{c, e, ~ h}$, Hanneke E. Hulst ${ }^{d, i}$, Dag Alnæs ${ }^{c}$

5 a Oslo University Hospital, Department of Neurology, Oslo, Norway

$6{ }^{b}$ University of Oslo, Institute of Clinical Medicine, Oslo, Norway

$7 \quad{ }^{c}$ NORMENT, Division of Mental Health and Addiction, Oslo, Norway

$8{ }^{\mathrm{d}}$ Vrije Universiteit Amsterdam, Department of Neuroscience, Amsterdam, The Netherlands

9 e University of Oslo, Department of Psychology, Oslo, Norway

$10{ }^{f}$ Bjørknes College, Oslo, Norway

$11 \mathrm{~g}$ Oslo University Hospital, Division of Radiology and Nuclear Medicine, Oslo, Norway

$12{ }^{\mathrm{h}}$ University of Oslo, KG Jebsen Centre for Neurodevelopmental Disorders, Oslo, Norway

13 i Amsterdam UMC, Amsterdam Neuroscience, Department of Anatomy and Neurosciences, MS Center

14 Amsterdam, Amsterdam, The Netherlands

15

* Einar August Høgestøl and Samuele Ghezzo contributed equally to this work as first authors.

Keywords: multiple sclerosis, functional neuroimaging, fMRI, cohort studies, all neuropsychological/behaviour

\section{Corresponding author:}

Einar August $\mathrm{H} \emptyset$ gestøl

Department of Neurology, Neuroscience Research Unit, Multiple Sclerosis Research Group University of

Oslo \& Oslo University Hospital

Domus Medica 4, room L-268, Gaustadalleén 34

0372 Oslo, Norway

E-mail: einar.august@gmail.com

Mobile: +4741 108981

Characters in title: 93 (Max 96)

Abstract: 249 (Max 250)

Introduction: 250 (Max 250)

Main text: 4269 (Max 4500)

References: 44 (Max 50)

Items: 7 (Max 7) 
medRxiv preprint doi: https://doi.org/10.1101/2020.06.19.20135558; this version posted June 20, 2020. The copyright holder for this preprint (which was not certified by peer review) is the author/funder, who has granted medRxiv a license to display the preprint in perpetuity.

It is made available under a CC-BY-NC-ND 4.0 International license .

\section{ABSTRACT}

36 Objective: 1) To assess fMRI-based functional connectivity (FC) anomalies in early multiple sclerosis

37 (MS), 2) To determine the relation between FC changes and structural brain damage due to disease

38 progression 3) To study the association between FC changes and cognitive and physical disability.

39 Methods: Structural MRI and resting-state fMRI were acquired from 76 early relapsing-remitting MS

40 patients at baseline (average disease duration 71.7 months \pm 63 ) and after five years. Ninety-four

41 healthy controls (HCS) matched for age and sex were included at baseline. Independent component

42 analysis (ICA) and network modelling were used to measure FC. FC variation was related to

43 expanded disability status scale and neuropsychological outcomes. Brain and lesion volumes were

44 quantified using standard methods. We used the 25 independent components obtained from ICA to

45 estimate the longitudinal stability of the brain connectome as a proxy for functional reorganization

46 over time.

47 Results: The MS subjects were clinically and cognitively stable. Compared to HCs, FC abnormalities

48 were detected within networks and in single connections in patients with early MS at baseline. Over

49 time, FC was relatively invariable, but changes in FC were associated with progression of brain

50 atrophy $(\rho=0.39, p=.06)$. No significant relationship with clinical and cognitive measures or lesion

51 load was detected.

52 Conclusion: Patients with MS showed evidence of altered FC in the early stages of the disease. Over

53 time, changes in FC seem to be related to a progression of brain atrophy, which are known to

54 precede changes in clinical and cognitive functioning. 
medRxiv preprint doi: https://doi.org/10.1101/2020.06.19.20135558; this version posted June 20, 2020. The copyright holder for this preprint (which was not certified by peer review) is the author/funder, who has granted medRxiv a license to display the preprint in perpetuity.

It is made available under a CC-BY-NC-ND 4.0 International license .

\section{INTRODUCTION}

56 Multiple sclerosis (MS) is a disease characterized radiologically by the accumulation of lesions in grey

57 and white matter over time throughout the $\mathrm{CNS}^{1,2}$. Brain white matter constitutes the structural

58 connectivity backbone supporting large-scale brain functional network connectivity ${ }^{3,4}$. Accumulating

59 evidence has demonstrated abnormal patterns of brain functional connectivity ( $F C$ ) in MS patients as

60 compared to healthy controls $(\mathrm{HCS})^{5-12}$. Extensive evidence shows that $\mathrm{FC}$ abnormalities are

61 associated with clinical disability in $\mathrm{MS}^{5,6,8-10,12}$, with a complex pattern of the directionality of FC

62 effects $^{13}$. A longitudinal approach that accounts for all alterations in FC following structural damage

63 in MS is warranted to better understand the complex interplay between disease progression and FC

64 reorganization ${ }^{13}$.

65 We investigated a prospectively collected MS cohort with comprehensive imaging and

66 clinical data at two time points over five years. First, we explored the baseline resting-state ( $\mathrm{rs}$ ) fMRI

67 MS-data and compared this to a group of age-matched HCs from the same scanner. Then, we used

rs-fMRI data to compute the longitudinal stability of each patients' brain functional connectome ${ }^{14}$,

reducing the complex dynamics of the functional connectome into a single, individual-level global

marker of longitudinal network reorganization. The resulting rs-fMRI global measure of connectome

stability was compared to brain atrophy, lesion load and clinical and cognitive outcomes. Our

hypotheses were 1) MS affects FC in early stages of disease, 2) disease progression is associated with

FC reorganization over a five-year interval and 3) an individual-level global measure of connectome

stability is associated with clinical trajectories in MS.

\section{METHODS}

\section{Participants}

77 We included 76 MS patients from a prospective longitudinal study at Oslo University Hospital ${ }^{15-17}$. All

78 patients were diagnosed between January 2009 and October 2012 with relapsing-remitting MS

79 (RRMS) according to the revised McDonald Criteria ${ }^{18}$. One patient originally categorized as RRMS 
medRxiv preprint doi: https://doi.org/10.1101/2020.06.19.20135558; this version posted June 20, 2020. The copyright holder for this preprint (which was not certified by peer review) is the author/funder, who has granted medRxiv a license to display the preprint in perpetuity.

It is made available under a CC-BY-NC-ND 4.0 International license .

80 was later re-evaluated to be primary-progressive (PP) MS, although with relapses and MRI activity.

81 The patient was excluded from image analysis due to missing rs-fMRI data. Early MS was defined as

82 within the first 10 years of MS symptoms onset. Six participants were not examined with the rs-fMRI

83 sequence at baseline, resulting in 70 patients eligible for the image analyses. All participants were

84 invited for follow-up, five years after the first time point. At follow-up, 62 patients were assessed,

85 with two patients missing the rs-fMRI sequence. Inclusion criteria included age between 18 and 50

86 years, $<3$ years since diagnosis of RRMS at baseline, $\geq 6$ weeks since the last relapse or corticoid

87 treatment, fluency in Norwegian language, right handedness, no prior neurological or psychiatric

disease, no head injury and no substance abuse. We excluded pregnant or breastfeeding patients

and a patient with a previous adverse reaction to gadolinium injection.

Cross-sectional data from $\mathrm{HC}$ ( $\mathrm{n}=94$, age- and sex-matched with respect to the patient sample) were sampled from the Norwegian Cognitive NeuroGenetics (NCNG) cohort, recruited through newspaper advertisements in the Oslo area ${ }^{19}$. Inclusion criteria were age between 20 and 80 years, no previous diseases affecting the CNS and no previous or current substance abuse.

\section{Neurological assessment}

All MS patients completed a comprehensive neurological examination at baseline and follow-up, hole peg test. No evidence of disease activity (NEDA) -3 was defined as the absence of clinical relapses, new or enlarging MRI lesions and clinical progression as measured by EDSS. First line treatment included interferons, glatiramer acetate, teriflunomide and dimethyl fumarate, while second line treatment included fingolimod, natalizumab and alemtuzumab. 
medRxiv preprint doi: https://doi.org/10.1101/2020.06.19.20135558; this version posted June 20, 2020. The copyright holder for this preprint (which was not certified by peer review) is the author/funder, who has granted medRxiv a license to display the preprint in perpetuity.

It is made available under a CC-BY-NC-ND 4.0 International license .

105

106

107

108

109

110

111

112

113

115

116

visuospatial and verbal memory (see Supplemental). In order to obtain a measure of average

cognition we first calculated Z-scores for each of the tests administered. Then, we averaged Z-scores within the four cognitive domains previously described, and eventually we averaged the scores across domains, obtaining a measure of overall cognition for each of the MS patients at both time points. Similarly, we averaged the Z-scores for T25-FW and 9-hole peg test to obtain a measure of physical ability.

Cross-sectional California Verbal Learning Test-II (CVLT-II) and colour-word interference test (CWIT) data from the NCNG HC sample and summary statistics for the remaining tests obtained from an Amsterdam HC sample ${ }^{22}$ were used for comparison with the patient group. We considered an annual decline of 0.25 SD in average cognition and physical performance as significant ${ }^{22}$.

\section{MRI acquisition and structural MRI pre- and post-processing}

All MS and HC subjects were scanned using the same 1.5 T scanner (Avanto, Siemens Medical Solutions; Erlangen, Germany) equipped with a 12-channel head coil. For rs-fMRI we used a T2* weighted echo-planar imaging (EPI) sequence (repetition time (TR)=3000 milliseconds (ms), echo time $(T E)=70 \mathrm{~ms}$, flip angle $(F A)=90^{\circ}$, voxel size $=3.44 \times 3.44 \times 4 \mathrm{~mm}$, field-of-view $(F O V)=220$, descending acquisition, GeneRalized Auto calibrating Partial Acquisition (GRAPPA) acceleration factor $=2$ ), 28 transversally oriented slices, no gap, with a scan time of 7 minutes and 30 seconds. The rs-fMRI at baseline included 150 volumes, while the follow-up rs-fMRI scan yielded 100 volumes. The rs-fMRI scan for the HCs constituted of 300 volumes. For fMRI pre-processing and analyses we restricted the rs-fMRI data to the first 100 volumes for all participants. Three dummy volumes were collected to avoid T1 saturation effects. Structural MRI data were collected using a 3D T1-weighted Magnetization Prepared Rapid Gradient Echo (MP-RAGE) sequence (TR=2400 ms, TE=3.61 ms, time to inversion $=1000 \mathrm{~ms}, \mathrm{FA}=8^{\circ}$, matrix $192 \times 192$, field of view $=240$, scan time 7 minutes and 42 seconds, sagittal slices $=160$, voxel size $=1.20 \times 1.25 \times 1.25 \mathrm{~mm}$ ). FLAIR sequence parameters were $T R=6000 \mathrm{~ms}, \mathrm{TE}=3.33 \mathrm{~ms}$, time to inversion=2200 ms, FOV=260, FA=variable T2, matrix $256 \times 204$. 
medRxiv preprint doi: https://doi.org/10.1101/2020.06.19.20135558; this version posted June 20, 2020. The copyright holder for this preprint (which was not certified by peer review) is the author/funder, who has granted medRxiv a license to display the preprint in perpetuity.

It is made available under a CC-BY-NC-ND 4.0 International license .

130 Each scan lasted 7 minutes and 2 seconds, sagital slices $=176$ slices, slice thickness $=1 \mathrm{~mm}$, voxel size

$131 \quad 1.0 \times 1.0 \times 1.0$

We performed cortical reconstruction by using the T1-weighted scans and volumetric segmentation with FreeSurfer 5.3 (http://surfer.nmr.mgh. harvard.edu/23 ${ }^{23}$ To extract reliable volume and thickness estimates, images included in the longitudinal MS MRI dataset were processed with the longitudinal stream in FreeSurfer ${ }^{24}$. To further validate the brain volume measure, we studied its association with lesion-filled masks at baseline (see table e-1 in Supplemental data). Lesion volume was based on LesionQuant output ${ }^{25,26}$. To validate the lesion output by LesionQuant we additionally assessed its association with lesion masks previously acquired using Cascade and validated by an experienced neuroradiologist at baseline ${ }^{27}$ (see table e-1 in Supplemental data).

\section{1 fMRI pre-processing}

fMRI was performed using FMRI Expert Analysis Tool (FEAT) Version 6.00, from FMRIB's Software 
medRxiv preprint doi: https://doi.org/10.1101/2020.06.19.20135558; this version posted June 20, 2020. The copyright holder for this preprint (which was not certified by peer review) is the author/funder, who has granted medRxiv a license to display the preprint in perpetuity.

It is made available under a CC-BY-NC-ND 4.0 International license .

155

156

157

158

159

160

161

162

163

164

165

166

167

168

169

170

171

172

173

174

175

176

177

178

179

using procedures for automated volumetric segmentation in Freesurfer 5.3

(http://surfer.nmr.mgh.harvard.edu/) ${ }^{23}$.

Single-session independent component analysis (ICA) was performed for all runs using

Multivariate Exploratory Linear Optimized Decomposition into Independent Components

$\left(\right.$ MELODIC) ${ }^{32}$. We used FIX ${ }^{33}$ for automatic classification of the single-session ICA into signal and noise components, in order to regress noise components from fMRI data. Data cleaning also included correction based on the estimated motion parameters for each run, using linear regression. These ICA-based procedures for denoising of fMRI-data efficiently reduce motion induced variability, outperforming methods based on regression of motion parameters, scrubbing or de-spiking ${ }^{34}$.

\section{ICA and functional connectivity matrices}

The cleaned and MNI-conformed rs-fMRI datasets were submitted to temporal concatenation group independent component analysis (gICA) using MELODIC ${ }^{32}$ with a model order of 40 . These group level spatial components were then used as spatial repressors against the original rs-fMRI datasets to estimate subject-specific components and associated time series (dual regression) ${ }^{35}$. After removing 15 ICs that originated in non-CNS areas and therefore were classified as noise components by a careful evaluation, we extracted a total of 25 ICs for further analysis. The times series of the noise-ICs were regressed out of the time series of the kept ICs. We then calculated connectivity matrices using full as well as regularized partial correlations with automatic estimation of regularization parameters at the individual leve ${ }^{36,37}$. Based on the Euclidean distances of the full temporal correlations, the ICs grouped into four clusters largely representing (1) and (2) default mode network (DMN) and frontoparietal areas, (3) auditory network and (4) sensory/motor areas (figure 1). For detailed information regarding the specific ICs or the anatomical constitution of the networks, please refer to table e-2 in Supplemental Data. Finally, since partial correlations are assumed to represent direct connections between nodes, these were used in further analyses of case-control differences and connectome stability. 
medRxiv preprint doi: https://doi.org/10.1101/2020.06.19.20135558; this version posted June 20, 2020. The copyright holder for this preprint (which was not certified by peer review) is the author/funder, who has granted medRxiv a license to display the preprint in perpetuity.

It is made available under a CC-BY-NC-ND 4.0 International license .

180
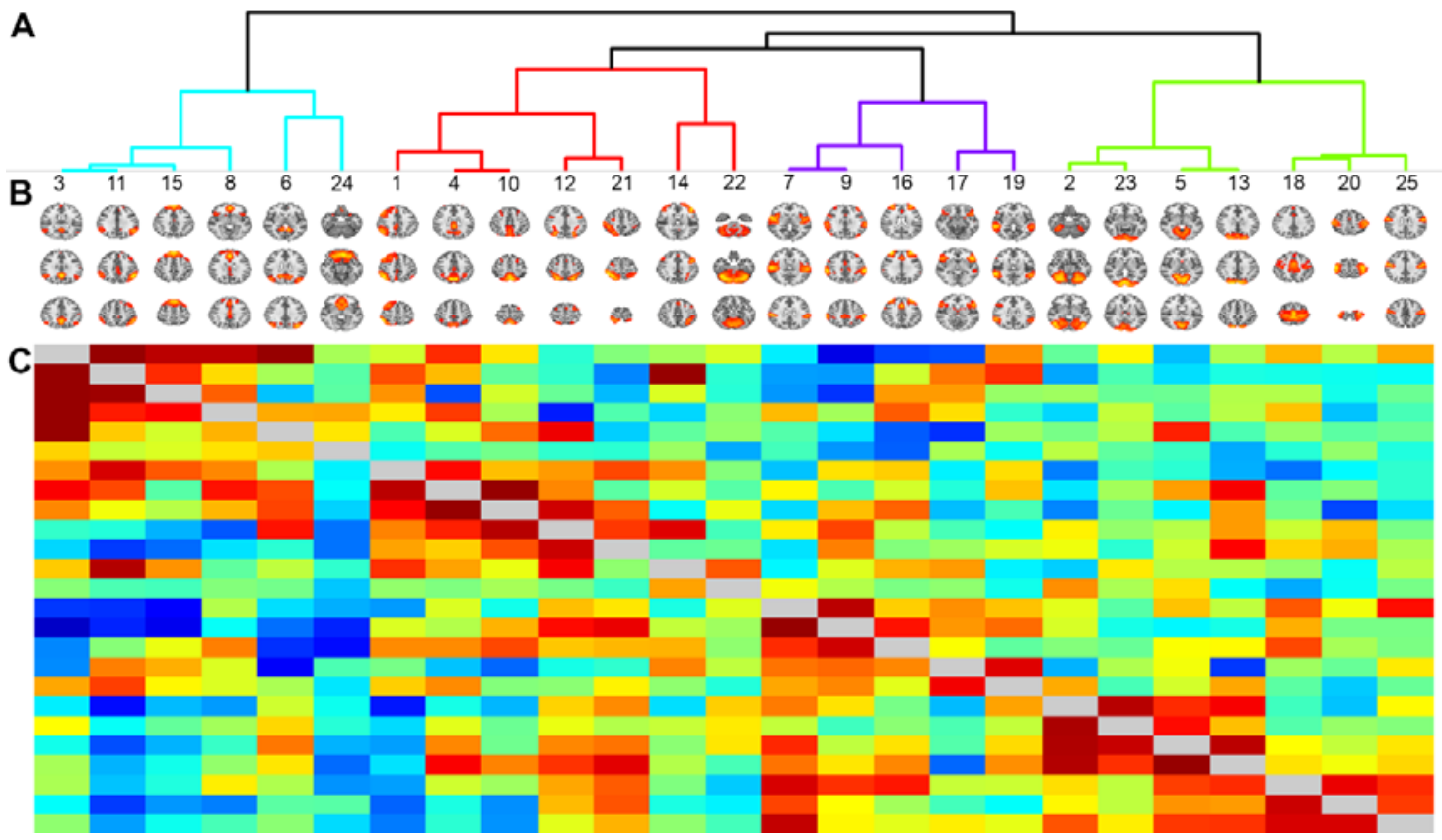

Figure 1 Hierarchical clustering of brain nodes. (A) Dendrogram showing the clustering of the nodes,

based on the full correlations across conditions and participants. The colours of the dendrograms

represent the four ICA clusters (1), (2), (3) and (4), from left to right. (B) The 25 ICs from group ICA

used in the analyses. (C) The full correlation matrix across conditions and participants is shown

below the diagonal. Regularized partial correlation across conditions are presented above the diagonal. Warm colours indicate positive correlations, cold colours negative correlations.

\section{Connectome stability}

We computed the stability of the brain functional connectome for each MS patient as a proxy for FC reorganization. We vectorized each participant's whole-brain connectivity matrix, creating a vector of size $1 \times 300$ ( 25 ICs and 300 unique links between them). Then, we calculated the within subjects Spearman correlation coefficient between $\mathrm{fMRI}$ at baseline and follow-up, in this way obtaining a measure of whole-brain connectome stability ${ }^{14}$. Similarly, we computed the within-network connectome stability for each of the four clusters previously identified. Alterations in the rank of edges across the connectome between baseline and follow-up, independent of their direction, will 
medRxiv preprint doi: https://doi.org/10.1101/2020.06.19.20135558; this version posted June 20, 2020. The copyright holder for this preprint (which was not certified by peer review) is the author/funder, who has granted medRxiv a license to display the preprint in perpetuity.

It is made available under a CC-BY-NC-ND 4.0 International license .

196 be reflected in the connectome stability, providing an individual global and network-specific

197 measure of FC reorganization for the MS patients. To further validate the implementation of the

198

stability of the brain functional connectome as a measure that accounts for all changes in FC over

time, we correlated connectome stability with the sum of the squared differences in FC between

baseline and FU for all edges in each of the MS patients.

\section{1}

\section{Statistical analysis}

For statistical analyses, we used $\mathrm{R}^{38}$ and MATLAB version 2014a (The MathWorks Inc., Natick, MA, 2018). The changes in performance for all cognitive and clinical tests between baseline and followup were measured by paired sample t-tests.

We used separate multivariate linear models to test for differences in whole brain FC, within network $\mathrm{FC}$, and $\mathrm{FC}$ at the level of single edges between $\mathrm{HCs}$ and MS patients at baseline. We performed paired sample t-tests to assess changes in FC over time in the MS cohort.

To investigate whether disease progression was associated with functional reorganization, we used separate multivariate linear models to compare whole brain, and with in network, connectome stability between patients that showed evidence of disease activity (EDA) and patients with NEDA. To further test the hypothesis that structural damage due to disease progression is associated with a reduction in the stability of the functional connectome we correlated whole brain functional connectome stability of EDA patients with measures of brain volume loss and accumulation of lesion load over five years. For lesion volumes we used log transformation, plus a constant $k=2$, to account for the lack of normal distribution in the resulting volumes.

Finally, we used multivariate linear models to assess the relationship between connectome stability with cognition and physical ability at follow-up, and on the change in these tests between baseline and follow-up.

We adjusted for sex, age, mean relative motion and signal to noise ratio in all linear models. Significance was defined as $p<.05$ in all the performed tests. In the first part of the study, when we 
medRxiv preprint doi: https://doi.org/10.1101/2020.06.19.20135558; this version posted June 20, 2020. The copyright holder for this preprint (which was not certified by peer review) is the author/funder, who has granted medRxiv a license to display the preprint in perpetuity.

It is made available under a CC-BY-NC-ND 4.0 International license .

compared FC between HCs and MS patients and later investigated changes in FC over time in the MS cohort, we corrected $\mathrm{p}$ value for multiple testing by false discovery rate. Due to the limited sample size of the subgroups, we used permutation testing to correct $p$ value for multiple testing in the comparisons of connectome stability between EDA and NEDA patients. Specifically, we obtained an empirical null-distribution of estimates for the group difference across 1000 permutations randomly permuting the group-label. The family wise error was controlled by collecting the maximum test statistic across the whole brain and within-network tests for each permutation ${ }^{39}$. The resulting $p$ value was calculated by dividing the number of permuted beta-values equal or larger than the point estimate by the total number of permutations.

\section{Standard protocols approval, registrations, and patient consents}

The project was approved by the regional ethical committee of South Eastern Norway (REC ID: 2011/1846, 2016/102 and 2009/2070), and all participants received oral and written information and gave their written informed consent.

\section{Data availability}

Summary data as published in this paper will be available, but other data are not publicly available because of patient privacy restrictions decided by the Regional Ethical Committee. We may apply for permission to share data with new collaborators, still adhering to patient privacy requirements of the "Law of Health Research". All code needed to replicate our described analyses is available upon request from the corresponding author.

\section{RESULTS}

\section{Sample characteristics at baseline and follow-up}

Our MS sample included $71 \%$ ( $N=54$ ) females, in line with the prevalence of MS in the general population. At follow-up 44\% ( $\mathrm{N}=27)$ of the patients met criteria for NEDA-3. The median EDSS (2.0) score did not change after five years. Only one patient developed secondary progressive MS (SPMS) at follow-up. Mean time between baseline and follow-up was 4.5 years $(S D=0.4$ years, range $=3.7$ - 
medRxiv preprint doi: https://doi.org/10.1101/2020.06.19.20135558; this version posted June 20, 2020. The copyright holder for this preprint (which was not certified by peer review) is the author/funder, who has granted medRxiv a license to display the preprint in perpetuity.

It is made available under a CC-BY-NC-ND 4.0 International license .

2465.4 years). Disease modifying treatment (DMT) were used by $78 \%$ and $69 \%$ of the patients at

247 baseline and follow-up, respectively (table 1). The proportion of patients using second line

248 treatment increased from $13 \%$ at baseline to $32 \%$ at follow-up. HCs were matched to the MS sample

249 at baseline by age ( $\mathrm{HC}$ mean years $=34.89, \mathrm{SD}=9.17)$ and $\operatorname{sex}(74 \%$ of $\mathrm{HC}$ were female $) .70 \%$ of $\mathrm{HCS}$

250 from the Amsterdam sample were females, (mean age years $=41.86, \mathrm{SD}=11.44$ ).

Table 1 Demographic and clinical characteristics of the multiple sclerosis patients

\begin{tabular}{lll}
\hline & Baseline & Follow-up \\
\hline (a) Demographic characteristics & $\mathrm{n}=76$ & $\mathrm{n}=62$ \\
\hline Female, $\mathrm{n}(\%)$ & $54(71)$ & $44(71)$ \\
\hline Age, mean years (SD) & $35.3(7.3)$ & \\
\hline Disease duration, mean months (SD) & $71.7(63)$ & $125.1(60.2)$ \\
\hline Age at first symptom, mean years (SD) & $29.3(6.7)$ & $66.4(14.5)$ \\
\hline Months since diagnosis, mean (SD) & $14.0(11.9)$ & \\
\hline Disease modifying treatment & & $19(31)$ \\
\hline None, $\mathrm{n}(\%)$ & $17(22)$ & $23(37)$ \\
\hline First line treatment, $\mathrm{n}(\%)$ & $49(65)$ & $20(32)$ \\
\hline Second line treatment, $\mathrm{n}(\%)$ & $10(13)$ & \\
\hline
\end{tabular}

\section{(b) Clinical evaluation}

\begin{tabular}{llc}
\hline \multicolumn{2}{l}{ Multiple sclerosis classification } & \\
\hline RRMS, $\mathrm{n}(\%)$ & $75(99)$ & $60(96)$ \\
\hline PPMS, $\mathrm{n}(\%)$ & $1(1)$ & $1(2)$ \\
\hline SPMS, $\mathrm{n}(\%)$ & & \\
\hline Neurological disability & & $2.0(1.3,0-6)$ \\
\hline EDSS, median (SD, range) & $2.0(0.9,0-6)$ & $2.6(1.8)$ \\
\hline MSSS (SD) & $4.9(1.9)$ & $2.6(1.3)$ \\
\hline Number of total relapses, mean (SD) & $1.8(1)$ &
\end{tabular}


medRxiv preprint doi: https://doi.org/10.1101/2020.06.19.20135558; this version posted June 20, 2020. The copyright holder for this preprint (which was not certified by peer review) is the author/funder, who has granted medRxiv a license to display the preprint in perpetuity.

It is made available under a CC-BY-NC-ND 4.0 International license .

FSS, mean (SD) $\quad 4.2(1.7) \quad 4.13(1.9)$

(c) NEDA assessment

$\begin{array}{ll}\text { NEDA-3, } \mathrm{n}(\%) & 27(44)\end{array}$

OCB, oligoclonal bands; RRMS, relapsing-remitting multiple sclerosis; PPMS, primary-progressive multiple sclerosis; SPMS, secondary-progressive multiple

sclerosis; EDSS, expanded disability status scale; MSSS, multiple sclerosis severity scale; FSS, fatigue severity scale; NEDA, no evidence of disease activity.

The performance of MS patients on all cognitive tests of the CWIT, in addition to the CVLT-II,

improved over time (table e-3 in Supplemental Data). The performance in symbol digit modalities

test, that also was used to investigate processing speed, did not change over time (table e-3 in

Supplemental Data). Both T25-FT and 9-hole peg test at follow-up did not show any significant

development when compared to baseline (table e-3 in Supplemental Data).

We found no effects of motion parameters such as signal to noise ratio and mean relative

motion with clinical and cognitive outcomes (table e-4 in Supplemental Data).

\section{Functional connectivity abnormalities in MS versus HCs at baseline}

Overall FC, for the complete combined functional connectome, was lower in MS patients compared

to HCs. FC within three of the four large-scale networks investigated was significantly decreased in

MS patients. After correction for multiple testing only network 1 and 2 remained significantly

different from controls (table 2). Edge wise analysis showed that a connection (IC11-IC15) in network

1 was weaker in MS relative to controls $(\beta=-0.1, t(135)=-5.21, p=.0002)$, while another (IC6-IC11)

one was stronger in patients compared to $\mathrm{HCs}(\beta=0.07, \mathrm{t}(135)=3.54, \mathrm{p}=.032)$. An edge (IC10-IC14)

in network 2 was increased in MS $(\beta=0.08, t(135)=3.74, p=.002)$ and within network 3 one

connection (IC7-IC16) decreased intensity in patients relative to controls $(\beta=-0.08, t(135)=-3.94, p$

$=.001$ ). Also, a connection (IC2-IC7) between networks 3 and 4 was altered in MS patients ( $\beta=-$ 
medRxiv preprint doi: https://doi.org/10.1101/2020.06.19.20135558; this version posted June 20, 2020. The copyright holder for this preprint (which was not certified by peer review) is the author/funder, who has granted medRxiv a license to display the preprint in perpetuity.

It is made available under a CC-BY-NC-ND 4.0 International license .

270 of single connections, showing that FC abnormalities are bidirectional in MS (figure e-1 in

271 Supplemental data for complete $\mathrm{p}$ values).

272 FC did not change significantly over time in the MS cohort, as measured by paired sample t-

273 test between all ICs considered singularly, and between ICs grouped into networks, across time

274 (figure e-2, e-3 and table e-5 in Supplemental Data). Additional analysis including careful lesion

275 masking during the estimation of the node time series did not change the main effects or

276 interpretation of the results (figure e-4 in Supplemental Data).

Table 2 Within network functional connectivity abnormalities in MS

\begin{tabular}{|c|c|c|c|c|}
\hline & Beta coefficient & T value & Standard deviation & P value \\
\hline Full brain & -0.001 & -1.28 & 0.001 & 0.2 \\
\hline Network 1 & -0.017 & -3.56 & 0.005 & $0.002 *$ \\
\hline \multicolumn{5}{|c|}{ DMN and frontoparietal nodes } \\
\hline Network 2 & -0.011 & -3.14 & 0.003 & $0.004 *$ \\
\hline \multicolumn{5}{|c|}{ DMN and frontoparietal nodes } \\
\hline Network 3 & -0.009 & -1.59 & 0.006 & 0.15 \\
\hline \multicolumn{5}{|c|}{ Auditory nodes } \\
\hline Network 4 & 0.002 & 0.41 & 0.005 & 0.68 \\
\hline Sensory anc & & & & \\
\hline
\end{tabular}


medRxiv preprint doi: https://doi.org/10.1101/2020.06.19.20135558; this version posted June 20, 2020. The copyright holder for this preprint (which was not certified by peer review) is the author/funder, who has granted medRxiv a license to display the preprint in perpetuity.

It is made available under a CC-BY-NC-ND 4.0 International license .

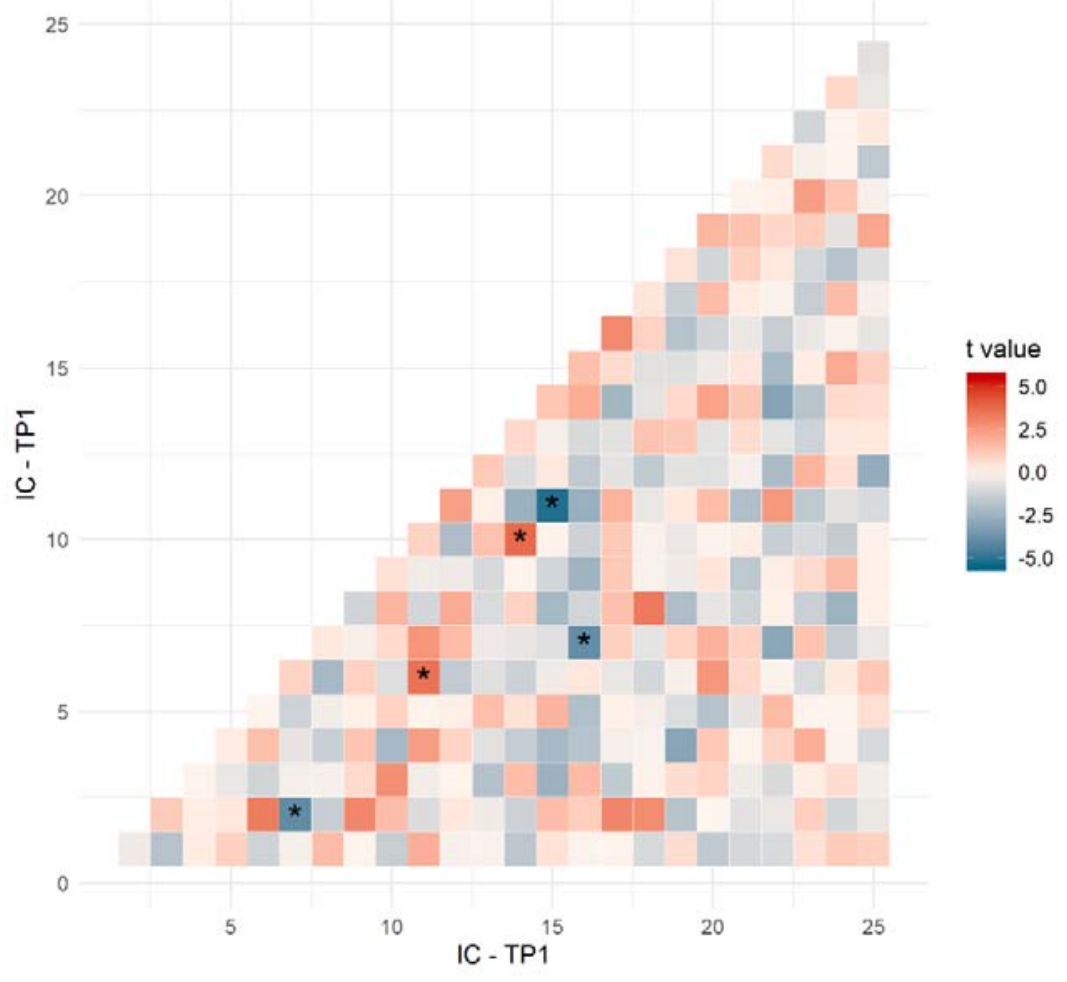

279 Figure 2 Edgewise analysis of functional connectivity abnormalities in MS vs HCs. T values form

280 multivariate linear regressions assessing differences in FC at the level of single connections between

281 MS and HCs. Warm colours indicate increased FC in MS, cold colours a decrease in FC. * P value significant after correction for multiple testing by false discovery rate.

\section{Connectome stability over time}

285 The stability of the brain functional connectome in the whole MS cohort, and in the EDA and NEDA

286 subgroups are depicted in Figure 3, enabling visualization of FC reorganization. Connectome stability

287 of network 2 was lower in EDA patients compared to NEDA patients $(\beta=0.14, t(34)=2.26, p=.03)$,

288 but did not survive correction for multiple testing (table e-6 in Supplemental Data). 


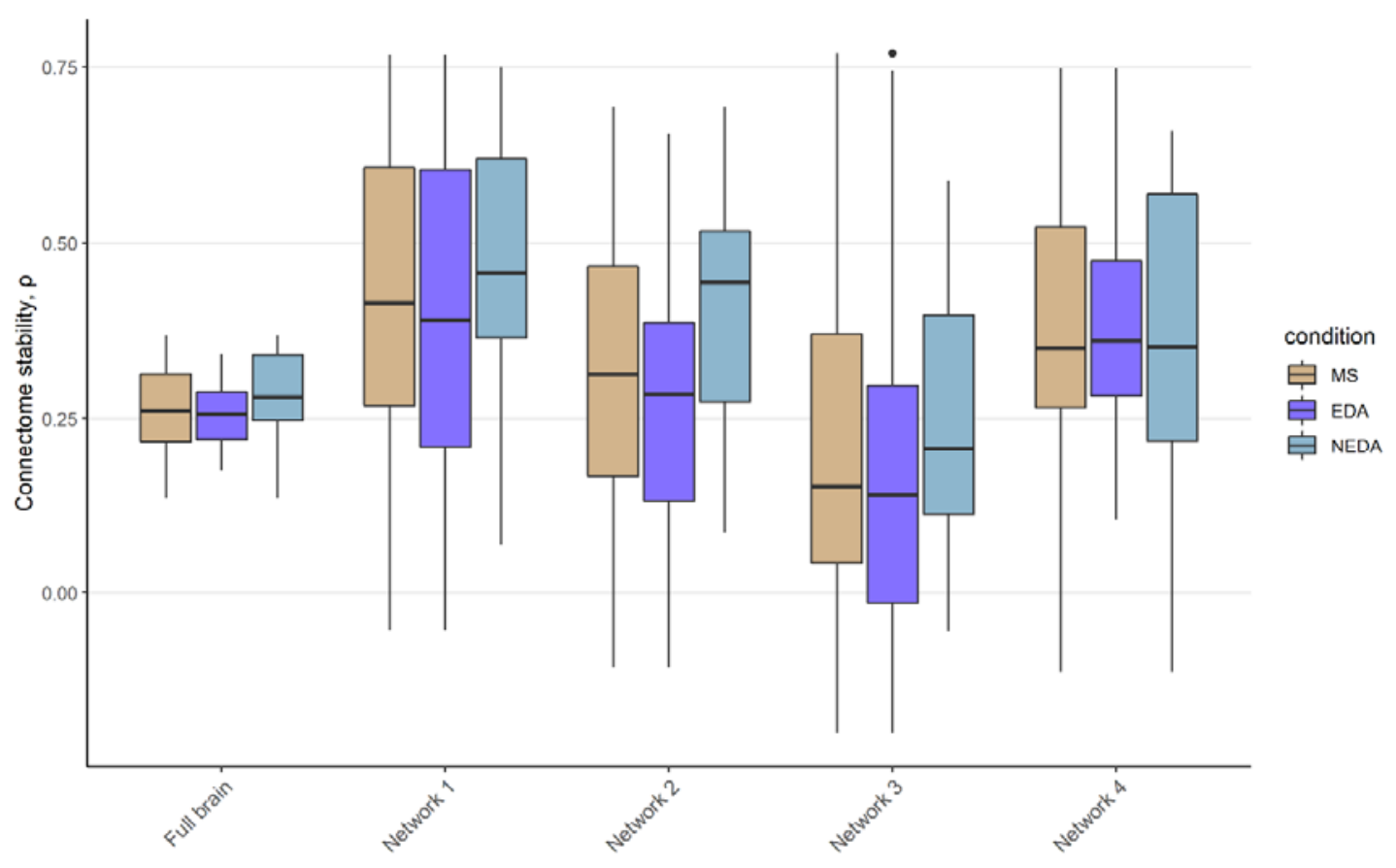

Figure 3 Stability of the brain functional connectome between baseline and follow-up for the MS

The analyses revealed a borderline significant association between connectome stability and change

in brain volume between baseline and follow-up, indicating that the larger changes in FC were

associated with increased brain volume loss over time, but no significant association was detected

with the accumulation of lesion volume over time (figure 4). We also checked for apparent relations

between motion parameters such as signal to noise ratio and mean relative motion and brain 
medRxiv preprint doi: https://doi.org/10.1101/2020.06.19.20135558; this version posted June 20, 2020. The copyright holder for this preprint (which was not certified by peer review) is the author/funder, who has granted medRxiv a license to display the preprint in perpetuity.

A

306

307

308

309

\section{Clinical relevance of functional connectivity changes}

$0.13, p=.63$.

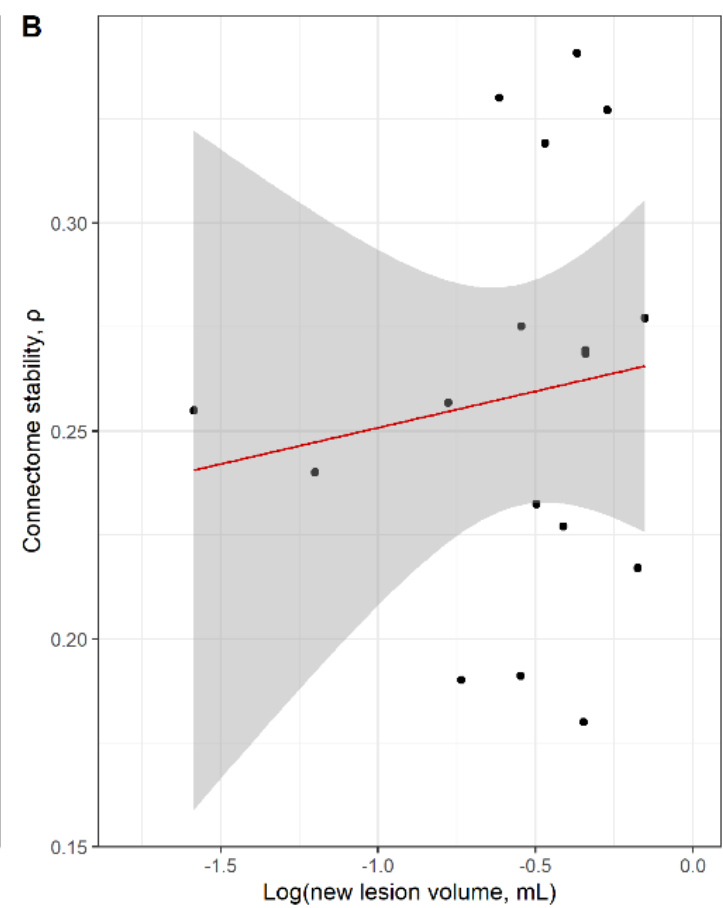

Figure 4 Correlation between structural damage and stability of the brain functional connectome.

(A) correlation between brain atrophy and the rate of FC reorganization, $\rho=0.40, p=.06$. (B)

correlation between accumulation of lesion volume over time and the rate of FC reorganization, $\rho=$

Finally, we explored the effects of the changes in FC on cognitive performance and physical ability using separate general linear models with average cognition and physical ability at FU as dependent variables, covarying for age, sex, signal to noise ratio and mean relative motion. Younger age at FU $(\beta=-0.03, t(34)=-2.08, p=.045)$ was associated with better cognitive performance at FU (figure $5 \mathrm{~A}$ ). Neither stability of the brain functional connectome, age, sex, signal to noise ratio nor mean relative motion were associated with longitudinal changes in cognitive performance ( $p>.05)$ (figure 5B). 
medRxiv preprint doi: https://doi.org/10.1101/2020.06.19.20135558; this version posted June 20, 2020. The copyright holder for this preprint (which was not certified by peer review) is the author/funder, who has granted medRxiv a license to display the preprint in perpetuity.

It is made available under a CC-BY-NC-ND 4.0 International license .

For physical ability, lower connectome stability $(\beta=4.56, t(34)=2.00, p=.05)$, higher age at

$319 \mathrm{FU}(\beta=-0.05, \mathrm{t}(34)=-2.45, \mathrm{p}=.02)$ and sex, with women scoring better than men, $(\beta=0.70, t(34)=$

$A_{1}$

c

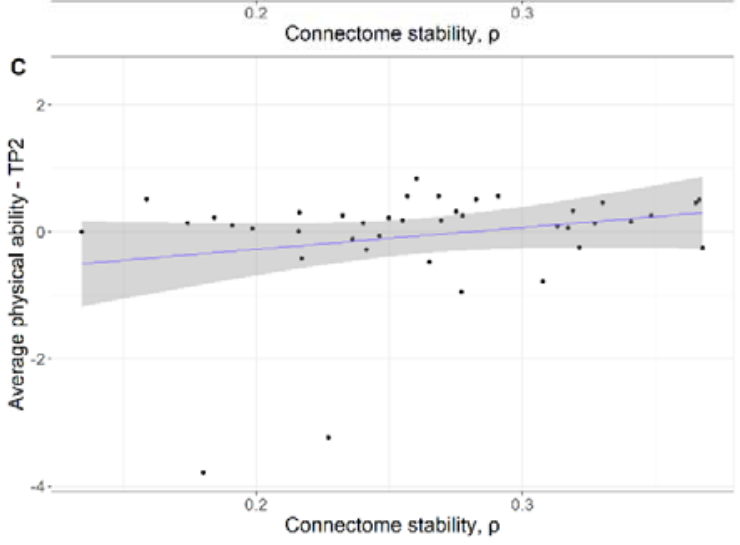

B

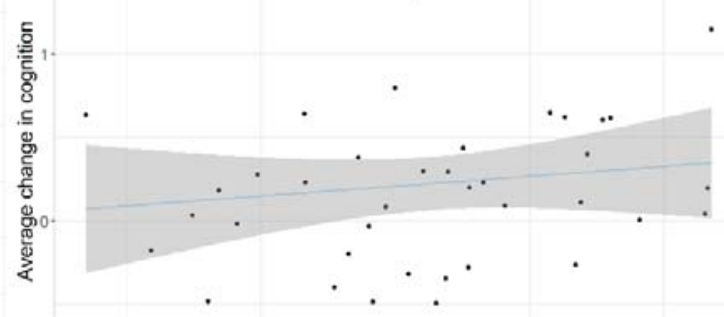

Connectome stability, $\rho$

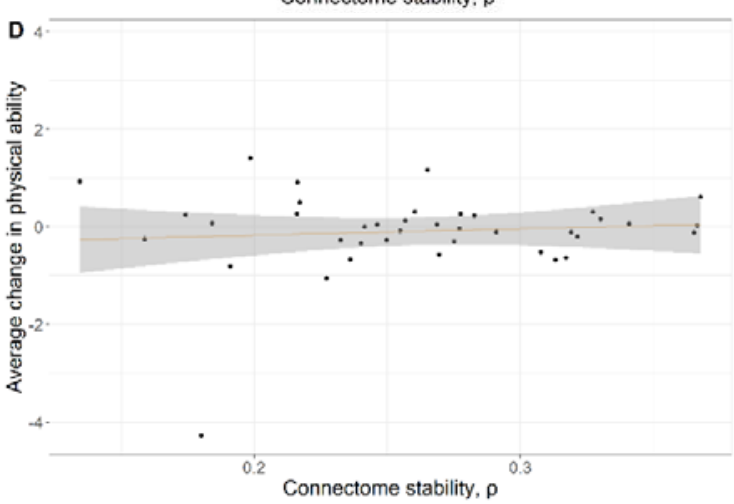

Figure 5 Effect of FC reorganization on cognitive performance and physical ability. (A) Effect of FC reorganization on average cognition at follow-up, $\beta=1.98, t(34)=1.20, p=.27$. (B) Effect of $F C$ reorganization on average change in cognition, $\beta=1.00, t(33)=0.64, p=.52$. (C) Effect of $F C$ reorganization on physical ability at follow-up, $\beta=4.56, t(34)=2.00, p=.05$. (D) Effect of $F C$ reorganization on average change in physical ability, $\beta=0.89, t(33)=0.33, p=.75$. 
medRxiv preprint doi: https://doi.org/10.1101/2020.06.19.20135558; this version posted June 20, 2020. The copyright holder for this preprint (which was not certified by peer review) is the author/funder, who has granted medRxiv a license to display the preprint in perpetuity.

It is made available under a CC-BY-NC-ND 4.0 International license .

331 In this study, we investigated clinical relevance of connectome stability as an individual-level global

332 marker of longitudinal FC changes, in a five years longitudinal prospective study of patients recently

333 diagnosed with MS. In addition, we performed a cross-sectional case-control comparison with a

334 matched group of healthy controls, assessing network- and edgewise FC differences between MS

335 patients and controls.

The case-control comparison replicated previous reports of bi-directional FC differences in

MS compared to a matched $\mathrm{HC}$ sample ${ }^{11,40}$, supporting our first hypothesis that $\mathrm{FC}$ aberrations are

present already in the early stages of MS.

Schoonheim et al. (2010) have proposed a model for functional reorganization of the brain

in relation to structural damage and clinical impairment in $\mathrm{MS}^{41}$, postulating that, at least in the early

stages of MS, functional connectivity would increase as a mechanism to suspend the effects of

microstructural damage occurring in the brain as a compensatory mechanism to delay clinical

disability. Since then, accumulating evidence has established that FC aberrations are in fact

bidirectional in $\mathrm{MS}^{11}$, and the authors recognized the first model postulated was overly simplified ${ }^{13}$.

345 Although their intuition and conceptualization of the model for FC reorganization following disease

progression in MS was valid, we hypothesize that their measure for FC reorganization was

incomplete.

In this study, we present a novel approach enabling us to study individual longitudinal FC

reorganization in relation to disease progression in MS. Investigating the longitudinal stability of the

brain functional connectome allows us to study the complex dynamics of FC reorganization in MS,

finally enabling us to test the model presented by Schoonheim et al. ${ }^{41}$, considering not only the

increase in $\mathrm{FC}$, but the whole complex interplay of $\mathrm{FC}$ changes following structural damage in MS.

In accordance with our hypothesis that disease progression in MS was associated with FC 
medRxiv preprint doi: https://doi.org/10.1101/2020.06.19.20135558; this version posted June 20, 2020. The copyright holder for this preprint (which was not certified by peer review) is the author/funder, who has granted medRxiv a license to display the preprint in perpetuity.

It is made available under a CC-BY-NC-ND 4.0 International license .

356

357

358

359

360

361

362

363

see increased FC reorganization in patients experiencing disease activity between baseline and follow-up. Connectome stability in network (2) was lower in EDA patients compared to NEDA patients, however the observed difference between these two sub-groups did not remain significant after correcting for multiple testing.

Finally, we assessed the clinical relevance of the connectome stability measure in our sample. We did not observe significant associations between connectome stability and progression of cognitive and physical impairment. A possible reason might be that our MS cohort was remarkably stable in the follow-up period, exemplified by observations that only two participants displayed a significant decrease (defined as an annual reduction of $>0.25$ SD in the five years followup period) in physical ability, and none in average cognition (figure e-5 and e-6 in Supplemental data respectively). Lower connectome stability was associated with lower physical ability at follow-up, but the result was likely to be driven by two outliers performing very poorly at follow-up. We did not detect any association between FC reorganization and average cognition at follow-up. According to the model presented by Schoonheim et $\mathrm{al}^{41}, \mathrm{FC}$ reorganization delays the onset of clinical impairment. Since we did not detect any worsening in the clinical performance of our MS patients during the observed period of time, it is tempting to speculate whether the FC changes, that occurred, delayed the onset of impairment. Therefore, it will be important to repeat these analyses in a planned follow-up of the group of patients in a few years.

Using connectome stability as an individual-level longitudinal measure, by incorporating the global dynamics of FC changes in the brain, has previously been used to study mental health in adolescent neurodevelopment ${ }^{42}$ as well as severe mental disorders ${ }^{14}$, but has so far remained unexplored in MS. The measure is based on longitudinal within-subjects Spearman correlation coefficients $^{14,42}$. Any change in FC that occurs over time, independent of the direction, will cause a shift in ranks that lowers the Spearman correlation coefficient, thus providing a global measure sensitive to relative $\mathrm{FC}$ reorganization. However, the shift in ranks of one connection causes the 
medRxiv preprint doi: https://doi.org/10.1101/2020.06.19.20135558; this version posted June 20, 2020. The copyright holder for this preprint (which was not certified by peer review) is the author/funder, who has granted medRxiv a license to display the preprint in perpetuity.

It is made available under a CC-BY-NC-ND 4.0 International license .

381

385

386

387

following shift in ranks of all the others, potentially inflating the measure of connectome stability.

We correlated the index of connectome stability with the sum of the squared differences in FC to control for possible artefacts due to the implementation of a rank-based measure. Since the correlation is strong, highly significant and goes in the expected direction we are confident that connectome stability is a valid approach to investigate $\mathrm{FC}$ reorganization in MS.

Our study is, to our knowledge, one of very few published studies investigating longitudinal $\mathrm{FC}$ in $\mathrm{MS}^{40,43}$. In general, our results reproduced and confirmed the results reported by Rocca et al and Koubiyr et al. (2019) investigating clinically isolated syndrome (CIS) patients in a longitudinal setting $^{40,43}$. All these studies show FC abnormalities at the early phases of the disease and, in line with Rocca et al. we found that FC alterations do not correlate with lesion volume. Furthermore, even though the main approach to study FC reorganization is different in these studies, all data-sets suggest brain reorganization during disease progression.

A limitation of our study is that we could not investigate the difference in connectome stability between HCs and MS patients due to the lack of MRI at follow-up for HCs. Since HCS performed cognitive tests only at baseline, we used the results of HCs at baseline to create the Zscores for MS patients at follow-up. Z-scores for physical ability were based on analyses of performance of MS patients only. Practice effects in cognitive tests seem to have occurred, but we could not account for them, for example calculating the reliable change index as done by Eijlers et al. ${ }^{22}$. The sample size of our MS cohort is comparable with that of previous studies investigating FC longitudinally ${ }^{40}$. In sub-group analyses the sample sizes are modest. Finally, functional connections of the brain are known to be dynamic, and future studies with longer scan duration may be able to pursue approaches for assessing the dynamic aspects of the FC in the brains of patients with MS.

To conclude, in this longitudinal study we found that our MS cohort was remarkably clinically stable. Only two patients showed a significant decrease in physical ability and cognitive performance was preserved in all participants in the follow-up period. We found that FC abnormalities are 
medRxiv preprint doi: https://doi.org/10.1101/2020.06.19.20135558; this version posted June 20, 2020. The copyright holder for this preprint (which was not certified by peer review) is the author/funder, who has granted medRxiv a license to display the preprint in perpetuity.

It is made available under a CC-BY-NC-ND 4.0 International license .

406 bidirectional and occur already at the early stages of MS. We used the stability of the brain

407 functional connectome as a proxy for FC reorganization, enabling us to study FC changes in relation to disease progression. We found that FC reorganization and brain atrophy advance in parallel. In future studies, the MS cohort needs to be followed up again to enable further analyses of functional brain changes and clinical course. Connectome stability enables fMRI data to be condensed into a proxy as an individual marker of brain health in a personalized medical approach to complement the existing biomarkers in $\mathrm{MS}^{44}$.

\section{Acknowledgement}

415 We thank all patients participating in our studies. We acknowledge the collaboration with members of the Multiple Sclerosis Research Group and NORMENT at the University of Oslo and Oslo University hospital, especially Elisabeth G. Celius for her guidance during the investigations of the MS patients and Tobias Kaufmann for valuable help and input on the statistical approach. We also thank the research assistants Kristin Liltved Grønsberg, May-Britt Gjengstø Utheim, Julia Timofeeva, Hedda of the patients.

\section{Study funding}

The project was supported by grants from the South-Eastern Health Authorities of Norway (grant 
medRxiv preprint doi: https://doi.org/10.1101/2020.06.19.20135558; this version posted June 20, 2020. The copyright holder for this preprint (which was not certified by peer review) is the author/funder, who has granted medRxiv a license to display the preprint in perpetuity.

It is made available under a CC-BY-NC-ND 4.0 International license .

429 E. A. Høgestøl has received honoraria for lecturing from Biogen, Merck and Sanofi-Genzyme, and

430 unrestricted research support from Merck and Sanofi-Genzyme. P. Sowa has received honoraria for

431 lecturing and travel support from Merck. M. K. Beyer has received honoraria for lecturing from

432 Novartis and Biogen Idec. H.F Harbo has received travel support, honoraria for advice or lecturing

433 from Biogen Idec, Sanofi-Genzyme, Merck, Novartis, Roche, and Teva and an unrestricted research

434 grant from Novartis. Hanneke Hulst received honoraria for speaking at scientific meetings, serving at

435 scientific advisory boards and consulting activities from Biogen, Celgene, Genzyme, Merck and

436 Roche. She has received research support from the Dutch MS Research foundation and serves on the

437 editorial board of Multiple Sclerosis Journal (MSJ). S. Ghezzo, G.O. Nygaard, T. Espeseth, L.T. Westlye

438 and D. Alnæs report no disclosures.

439 Appendix

440 Authors

\begin{tabular}{|c|c|c|}
\hline Name & Location & Contribution \\
\hline Einar A. Høgest $\varnothing$, MD & $\begin{array}{l}\text { Oslo University Hospital \& } \\
\text { University of Oslo }\end{array}$ & $\begin{array}{l}\text { Conceived the study, data } \\
\text { collection conception and design } \\
\text { of the work, data } \\
\text { analysis and interpretation, } \\
\text { drafting the article, final approval } \\
\text { of the version to be published }\end{array}$ \\
\hline Samuele Ghezzo, BSc & $\begin{array}{l}\text { Oslo University Hospital \& } \\
\text { University of Oslo }\end{array}$ & $\begin{array}{l}\text { Data analysis and interpretation, } \\
\text { drafting the article, final approval } \\
\text { of the version to be published }\end{array}$ \\
\hline Gro O. Nygaard, PhD & Oslo University Hospital & $\begin{array}{l}\text { Conceived the study, data } \\
\text { collection conception and design } \\
\text { of the work, final approval of the } \\
\text { version to be published }\end{array}$ \\
\hline Thomas Espeseth, PhD & $\begin{array}{l}\text { University of Oslo \& Bjørknes } \\
\text { College }\end{array}$ & $\begin{array}{l}\text { Data collection, final approval of } \\
\text { the version to be published }\end{array}$ \\
\hline Piotr Sowa, MD, PhD & Oslo University Hospital & $\begin{array}{l}\text { Data collection, final approval of } \\
\text { the version to be published }\end{array}$ \\
\hline Mona K. Beyer, PhD & $\begin{array}{l}\text { Oslo University Hospital \& } \\
\text { University of Oslo }\end{array}$ & $\begin{array}{l}\text { Data collection and design of the } \\
\text { work, final approval of the version } \\
\text { to be published }\end{array}$ \\
\hline Hanne F. Harbo, PhD & $\begin{array}{l}\text { Oslo University Hospital \& } \\
\text { University of Oslo }\end{array}$ & $\begin{array}{l}\text { Conceived the study, data } \\
\text { collection, conception and design } \\
\text { of the work, final approval of the } \\
\text { version to be published }\end{array}$ \\
\hline Lars T. Westlye, PhD & $\begin{array}{l}\text { Oslo University Hospital \& } \\
\text { University of Oslo }\end{array}$ & $\begin{array}{l}\text { Data analysis and interpretation, } \\
\text { final approval of the version to be }\end{array}$ \\
\hline
\end{tabular}


medRxiv preprint doi: https://doi.org/10.1101/2020.06.19.20135558; this version posted June 20, 2020. The copyright holder for this preprint (which was not certified by peer review) is the author/funder, who has granted medRxiv a license to display the preprint in perpetuity.

It is made available under a CC-BY-NC-ND 4.0 International license .

\begin{tabular}{lll}
\hline Hanneke E. Hulst, PhD & $\begin{array}{l}\text { Amsterdam UMC \& Vrije } \\
\text { Universiteit Amsterdam }\end{array}$ & $\begin{array}{l}\text { Data analysis and interpretation, } \\
\text { drafting the article, final approval } \\
\text { of the version to be published }\end{array}$ \\
\hline Dag Alnæs, PhD & $\begin{array}{l}\text { Oslo University Hospital \& } \\
\text { University of Oslo }\end{array}$ & $\begin{array}{l}\text { drafting the article, final approval } \\
\text { of the version to be published }\end{array}$ \\
\hline
\end{tabular}

441

1. Barkhof $F$. The clinico-radiological paradox in multiple sclerosis revisited. Current opinion in neurology 2002;15:239-245.

$445 \quad 2 . \quad$ Chard D, Trip SA. Resolving the clinico-radiological paradox in multiple sclerosis. F1000Res $446 \quad 2017 ; 6: 1828$.

447 3. Peer M, Nitzan M, Bick AS, Levin N, Arzy S. Evidence for Functional Networks with in the 448 Human Brain's White Matter. J Neurosci 2017;37:6394-6407.

449 4. Smith SM, Fox PT, Miller KL, et al. Correspondence of the brain's functional architecture 450 during activation and rest. Proceedings of the National Academy of Sciences of the United States of 451 America 2009;106:13040-13045.

$452 \quad 5 . \quad$ Basile B, Castelli M, Monteleone F, et al. Functional connectivity changes with in specific 453 networks parallel the clinical evolution of multiple sclerosis. Multiple sclerosis (Houndmills, 454 Basingstoke, England) 2014;20:1050-1057.

455 6. Rocca MA, Valsasina P, Martinelli V, et al. Large-scale neuronal network dysfunction in 456 relapsing-remitting multiple sclerosis. Neurology 2012;79:1449-1457.

457 7. d'Ambrosio A, Valsasina P, Gallo A, et al. Reduced dynamics of functional connectivity and 458 cognitive impairment in multiple sclerosis. Multiple sclerosis (Houndmills, Basingstoke, England) 459 2019:1352458519837707.

460 8. Rocca MA, Valsasina P, Leavitt VM, et al. Functional network connectivity abnormalities in 461 multiple sclerosis: Correlations with disability and cognitive impairment. Multiple sclerosis 462 (Houndmills, Basingstoke, England) 2018;24:459-471.

463 9. Hawellek DJ, Hipp JF, Lewis CM, Corbetta M, Engel AK. Increased functional connectivity 464 indicates the severity of cognitive impairment in multiple sclerosis. Proceedings of the National 465 Academy of Sciences of the United States of America 2011;108:19066-19071.

466 10. Rocca MA, Valsasina $\mathrm{P}, \mathrm{Absinta} \mathrm{M}$, et al. Default-mode network dysfunction and cognitive 467 impairment in progressive MS. Neurology 2010;74:1252-1259.

468 11. TahedI M, Levine SM, Greenlee MW, Weissert R, Schwarzbach JV. Functional Connectivity in 469 Multiple Sclerosis: Recent Findings and Future Directions. Frontiers in neurology 2018;9:828.

470 12. Faivre A, Rico A, Zaaraoui W, et al. Assessing brain connectivity at rest is clinically relevant in 471 early multiple sclerosis. Multiple sclerosis (Houndmills, Basingstoke, England) 2012;18:1251-1258.

472 13. Schoonheim MM, Meijer KA, Geurts JJ. Network collapse and cognitive impairment in 473 multiple sclerosis. Frontiers in neurology 2015;6:82.

474 14. Kaufmann T, Alnaes D, Brandt CL, et al. Stability of the Brain Functional Connectome 475 Fingerprint in Individuals With Schizophrenia. JAMA psychiatry 2018;75:749-751.

476 15. Nygaard GO, Walhovd KB, Sowa P, et al. Cortical thickness and surface area relate to specific 477 symptoms in early relapsing-remitting multiple sclerosis. Multiple sclerosis (Houndmills, Basingstoke, 478 England) 2015;21:402-414.

479 16. Nygaard GO, Celius EG, de Rodez Benavent SA, et al. A Longitudinal Study of Disability, 480 Cognition and Gray Matter Atrophy in Early Multiple Sclerosis Patients According to Evidence of 481 Disease Activity. PloS one 2015;10:e0135974. 
medRxiv preprint doi: https://doi.org/10.1101/2020.06.19.20135558; this version posted June 20, 2020. The copyright holder for this preprint (which was not certified by peer review) is the author/funder, who has granted medRxiv a license to display the preprint in perpetuity.

It is made available under a CC-BY-NC-ND 4.0 International license .

17. Høgest $\varnothing \mid$ EA, Kaufmann T, Nygaard GO, et al. Cross-Sectional and Longitudinal MRI Brain Scans Reveal Accelerated Brain Aging in Multiple Sclerosis. Frontiers in neurology 2019;10.

18. Polman CH, Reingold SC, Banwell B, et al. Diagnostic criteria for multiple sclerosis: 2010 revisions to the McDonald criteria. Annals of neurology 2011;69:292-302.

19. Espeseth T, Christoforou A, Lundervold AJ, Steen VM, Le Hellard S, Reinvang I. Imaging and cognitive genetics: the Norwegian Cognitive NeuroGenetics sample. Twin Res Hum Genet 2012;15:442-452.

20. Krupp LB, LaRocca NG, Muir-Nash J, Steinberg AD. The fatigue severity scale. Application to patients with multiple sclerosis and systemic lupus erythematosus. Archives of neurology 1989;46:1121-1123.

21. Penner IK, Paul F. Fatigue as a symptom or comorbidity of neurological diseases. Nature reviews Neurology 2017.

22. Eijlers AJC, van Geest Q, Dekker I, et al. Predicting cognitive decline in multiple sclerosis: a 5year follow-up study. Brain : a journal of neurology 2018;141:2605-2618.

23. Dale AM, Fischl B, Sereno MI. Cortical surface-based analysis. I. Segmentation and surface reconstruction. Neurolmage 1999;9:179-194.

24. Reuter M, Schmansky NJ, Rosas HD, Fischl B. Within-subject template estimation for unbiased longitudinal image analysis. Neurolmage 2012;61:1402-1418.

25. Brewer JB. Fully-automated volumetric MRI with normative ranges: translation to clinical practice. Behav Neurol 2009;21:21-28.

26. W. Luo KL, A. M. Ulug, J. Albright, S. Magda, R. Haxton, C. Airriess. Lesion Quant Performance Evaluation

Accuracy and Reproducibility (white paper): Cortechs Labs, 2017.

27. Damangir S, Manzouri A, Oppedal K, et al. Multispectral MRI segmentation of age related white matter changes using a cascade of support vector machines. Journal of the neurological sciences 2012;322:211-216.

28. Smith SM, Jenkinson M, Woolrich MW, et al. Advances in functional and structural MR image analysis and implementation as FSL. Neurolmage 2004;23 Suppl 1:S208-219.

29. Jenkinson $M$, Bannister $P$, Brady M, Smith S. Improved optimization for the robust and accurate linear registration and motion correction of brain images. Neurolmage 2002;17:825-841.

30. Smith SM. Fast robust automated brain extraction. Human brain mapping 2002;17:143-155.

31. Smith SM, Brady JM. SUSAN-A New Approach to Low Level Image Processing. International Journal of Computer Vision 1997;23:45-78.

32. Beckmann CF, DeLuca M, Devlin JT, Smith SM. Investigations into resting-state connectivity using independent component analysis. Philosophical transactions of the Royal Society of London Series B, Biological sciences 2005;360:1001-1013.

33. Griffanti L, Salimi-Khorshidi G, Beckmann CF, et al. ICA-based artefact removal and accelerated fMRI acquisition for improved resting state network imaging. Neurolmage 2014;95:232247.

34. Pruim RH, Mennes M, van Rooij D, Llera A, Buitelaar JK, Beckmann CF. ICA-AROMA: A robust ICA-based strategy for removing motion artifacts from fMRI data. Neurolmage 2015;112:267-277. 35. Nickerson LD, Smith SM, Ongur D, Beckmann CF. Using Dual Regression to Investigate Network Shape and Amplitude in Functional Connectivity Analyses. Front Neurosci 2017;11:115. 36. Ledoit $\mathrm{O}$, Wolf $\mathrm{M}$. Improved estimation of the covariance matrix of stock returns with an application to portfolio selection. Journal of Empirical Finance 2003;10:603-621.

37. Brier MR, Mitra A, McCarthy JE, Ances BM, Snyder AZ. Partial covariance based functional connectivity computation using Ledoit-Wolf covariance regularization. Neurolmage 2015;121:29-38. 38. R: A Language and Environment for Statistical Computing [computer program]. Vienna, Austria: R Foundation for Statistical Computing, 2017.

39. Singh KD, Barnes GR, Hillebrand A. Group imaging of task-related changes in cortical synchronisation using nonparametric permutation testing. Neurolmage 2003;19:1589-1601. 
medRxiv preprint doi: https://doi.org/10.1101/2020.06.19.20135558; this version posted June 20, 2020. The copyright holder for this preprint (which was not certified by peer review) is the author/funder, who has granted medRxiv a license to display the preprint in perpetuity.

It is made available under a CC-BY-NC-ND 4.0 International license.

533 40. Rocca MA, Hidalgo de La Cruz M, Valsasina P, et al. Two-year dynamic functional network 534 connectivity in clinically isolated syndrome. Multiple sclerosis (Houndmills, Basingstoke, England) 535 2019:1352458519837704.

536 41. Schoonheim MM, Geurts JJ, Barkhof $F$. The limits of functional reorganization in multiple 537 sclerosis. Neurology 2010;74:1246-1247.

538 42. Kaufmann T, Alnaes D, Doan NT, Brandt CL, Andreassen OA, Westlye LT. Delayed

539 stabilization and individualization in connectome development are related to psychiatric disorders.

$540 \quad$ Nature neuroscience 2017.

541 43. Koubiyr I, Besson P, Deloire M, et al. Dynamic modular-level alterations of structural-

542 functional coupling in clinically isolated syndrome. Brain : a journal of neurology 2019;142:3428-

5433439.

544 44. Giovannoni G, Butzkueven $\mathrm{H}$, Dhib-Jalbut S, et al. Brain health: time matters in multiple

545 sclerosis. Multiple sclerosis and related disorders 2016;9 Suppl 1:S5-S48.

546 